\title{
Peran perempuan dan penduduk terdidik dalam upaya mencapai target sustainable development goals di Indonesia
}

\author{
Isti Larasati Widiastuty \\ Badan Pusat Statistik Provinsi Jawa Barat. Jalan PH.H. Mustofa No.43, Neglasari, Cibeunying \\ Kaler, Kota Bandung, Jawa Barat 40124, Indonesia \\ Corresponding Author. Email: isti@bps.go.id \\ Received: 8 November 2018; Revised: 10 December 2018; Accepted: 21 December 2018
}

\begin{abstract}
Abstrak
Penelitian ini bertujuan untuk mengetahui perkembangan ketenagakerjaan di Indonesia, peran perempuan dan penduduk terdidik dalam pencapaian target Sustainable Development Goals (SDGs) di Indonesia. Mencapai tujuan SDGs memerlukan partisipasi, kerja dan sinergitas yang komprehensif dari berbagai pihak. Penelitian ini ingin menyoroti bagaimana mencapai target kedelapan SDGs dengan memperhatian peran perempuan dalam pembangunan dan aktivitas kerja. Metode analisis yang digunakan adalah analisis dekriptif dan analisis statistik regresi linier berganda. Sumber data yang digunakan berasal dari Badan Pusat Statistik (BPS). Beberapa indikator ketenagakerjaan menunjukkan tren meningkat dari 2010 - 2018. Penduduk terdidik mendominasi kegiatan bekerja dan penganggur di Indonesia. Pada tahun 2018 jumlah penganggur terdidik sebanyak $65,89 \%$ dari total penganggur. Variabel yang mempengaruhinya adalah rata-rata upah, tingkat kemiskinan, tingkat kesempatan kerja terdidik, jumlah penduduk miskin dan jumlah penduduk usia kerja, dengan koefisien determinasi o,959. Partisipasi perempuan dalam aktivitas kerja dan sumbangan pendapatannya dalam ekonomi lebih rendah daripada laki-laki, namun secara tren menunjukkan peningkatan.
\end{abstract}

Kata Kunci: SDGs, pengangguran terdidik, kerja, gender

\section{The role women and educated population in effort to achieve sustainable development goals in Indonesia}

\footnotetext{
Abstract

This study aims to determine the development of employment in Indonesia, the role of women and educated residents in achieving the targets of Sustainable development Goals (SDGs) in Indonesia. Achieving the goals s of SDGs requires comprehensive participation, work and synergy from stakeholders. This study wants to highlinght how to reach the eighth target of SDGs bay paying attention to the role of women in development and work activities. The analytical method used descriptive analysis and statistical analysis of multiple linier regression. The data source used is secondary data from Statistics Indonesia (BPS). During this period several employment indicators showed an increasing trend each year. Educated population dominates work activities and unemploment people in Indonesia. In 2018 the number of educated unemployment reached $65,89 \%$ of the total unemployed people in Indonesia. The variables that influence it are average wages, poverty levels, educated employent rates, the number of poor people and the number of working-age population, with a coefficient of determination arround 0.959. women's participation in work activities and the contribution of their income in the economy is lower than men, but in trend shows an increase.

Keywords: SDGs, educated unemploment, work, gender

How to Cite: Widiastuty, I. (2018). Peran perempuan dan penduduk terdidik dalam upaya mencapai target sustainable development goals di Indonesia. JPPM (Jurnal Pendidikan dan Pemberdayaan Masyarakat), 5(2), 154-166. doi:https://doi.org/10.21831/jppm.v5i2.21925

d

https://doi.org/10.21831/jppm.v5i2.21925
}

Copyright (c) 2018, JPPM, ISSN 2355-1615 (print), ISSN 2477-2992 (online) 
JPPM (Jurnal Pendidikan dan Pemberdayaan Masyarakat), 5 (2), 2018 - 155

Isti Larasati Widiastuty

\section{PENDAHULUAN}

Mencapai tujuan Sustainable Development Goals (SDGs) memerlukan partisipasi, kerja dan sinergitas yang komprehensif dari berbagai pihak. Penelitian ini ingin menyoroti bagaimana mencapai target kedelapan SDGs dengan memperhatian peran perempuan dan penduduk terdidik dalam pembangunan dan aktivitas kerja. Tujuan kedelapan SDGs yaitu meningkatkan pertumbuhan ekonomi yang inklusif dan berkelanjutan, kesempatan kerja yang produktif dan menyeluruh, serta pekerjaan yang layak untuk semua. Tujuan ini dapat dicapai jika program dilakukan dari berbagai aspek dan dimensi.

Permasalahan penurunan tingkat pengangguran di Indonesia masih menjadi sebuah persoalan. Pada rilis data ketenagakerjaan 5 November 2018 lalu, tercatat bahwa tingkat pengangguran terbuka (TPT) Agustus 2018 sedikit menurun dibandingkan TPT Agustus 2017, yaitu sebesar 5,34\%. Padahal berbagai program dan anggaran telah digulirkan, diantaranya program alokasi dana desa. Sejak tahun 2015, total anggaran dana desa yang dikucurkan sampai dengan tahap 2 tahun 2018 telah mencapai 149,31 triliun rupiah (Sekretariat Kabinet Republik Indonesia, 2018). Sejak lama pemerintah telah memiliki kebijakan tripple strategy yakni progrowth, propoor, dan proemployment (Muhdar, 2015). Melalui kebijakan ini diharapkan pertumbuhan akan berkelanjutan melalui peningkatan tenaga kerja dan produktivitasnya, sebagai strategi dalam menurunkan tingkat kemiskinan (Klasen, 2010).

Berbagai program penurunan tingkat pengangguran telah banyak dilakukan, baik oleh pemerintah, swasta, maupun pada level komunitas, termasuk program pemberdayaan masyarakat dalam upaya menekan pengangguran dan tingkat kemiskinan. Penelitian Cutler dan Katz menunjukkan bahwa pengangguran memiliki pengaruh kuat terhadap tingkat kemiskinan (Cutler \& Katz, 1991). Oleh karena itu, sinergitas program keduanya penting dilakukan.

Dalam pelaksanaan program diperlukan basis data yang kuat agar program dapat dijalankan tepat sasaran dan sesuai dengan target yang ditentukan. Berbagai penelitian sudah banyak dilakukan terkait pengangguran, namun masih sedikit penelitian yang mengungkap bagaimana peran kerja perempuan. Penelitian International Labour Organization (ILO) mengungkapkan bahwa hasil yang dicapai laki-laki dan perempuan dalam ketenagakerjaan masih tidak merata (International Labour Organization, 2008).

Persoalan lain yang juga dihadapi terkait pengangguran adalah kompetensi para pencari kerja belum link and match dengan industri (Jubaedah, Rohaeni, \& Tati, 2015). Faktor pendorong pengangguran terdidik lainnya adalah ketidakcocokan (mismatch) antara keluaran pendidikan dan kesempatan kerja(Badan Pusat Statistik, 2008). Menyelaraskan dunia pendidikan dan dunia kerja adalah suatu keniscayaan (Intan, 2014). Penelitian terkait perempuan yang tergolong pengangguran terdidik pun masih jarang dilakukan. Penelitian ini akan memberikan gambaran bagaimana profil ketenagakerjaan perempuan dan pengangguran terdidik perempuan di Indonesia.

Terkait konsep ketenagakerjaan yang digunakan dalam penelitian ini adalah konsep ILO. Berdasarkan "An ILO Manual on Concepts and Methods" (International Labour Organization, 2013) penduduk usia kerja adalah penduduk berumur 15 tahun dan lebih. Penduduk yang termasuk angkatan kerja adalah penduduk usia kerja (15 tahun dan lebih) yang bekerja, atau punya pekerjaan namun sementara tidak bekerja dan pengangguran. Bekerja adalah kegiatan ekonomi yang dilakukan oleh seseorang dengan maksud memperoleh atau membantu memperoleh pendapatan atau keuntungan, paling sedikit 1 jam (tidak terputus) dalam seminggu yang lalu. Kegiatan tersebut termasuk pola kegiatan pekerja tak dibayar yang membantu dalam suatu usaha/kegiatan ekonomi. Penganggur terbuka adalah mereka yang: (1) tidak mempunyai pekerjaan dan mencari pekerjaan, (2) tidak mempunyai pekerjaan dan mempersiapkan usaha, (3) tidak mempunyai pekerjaan dan tidak mencari pekerjaan, (4) merasa tidak mungkin mendapatkan pekerjaan, (5) sudah mem- 
punyai pekerjaan tetapi belum mulai bekerja (Badan Pusat Statistik, 2018b)

Penganggur terdidik adalah angkatan kerja berpendidikan menengah ke atas dan tidak bekerja. Jika didasarkan pada kebijakan pemerintah tentang wajib belajar 9 tahun, maka golongan terdidik adalah golongan di mana telah menempuh kewajiban pendidikan dasar dan kemudian memutuskan untuk melanjutkan ke tingkat pendidikan yang lebih tinggi (Mada \& Ashar, 2015)

Fenomena yang terjadi adalah pengangguran terdidik mendominasi pengangguran di Indonesia. Penganggur di Indonesia didominasi oleh penganggur berpendidikan menengah dan tinggi (di atas SMA). Kondisi Agustus 2018, persentase penganggur dengan pendidikan SMA ke atas mencapai 65,89\%. Tingkat pengangguran terbuka (TPT) pada jenjang pendidikan SMK Agustus 2018 mencapai 11,24\%, dua kali lipat dari TPT total.

Penelitian terdahulu menyatakan, "semakin tinggi tingkat pendidikan penduduk, maka semakin besar kontribusinya dalam perekonomian"(Badan Pusat Statistik, 2008). Berkontribusi dalam perekonomian artinya terlibat dan berpartisipasi dalam dunia kerja. Tentunya akan menjadi persoalan ketika semakin tinggi tingkat pendidikan, tetapi tingkat pengangguran pada jenjang tersebut juga tinggi. Penting dilihat bagaimana gambaran terkini terkait karakteristik pengangguran terdidik di Indonesia. Terutama jika dikaitkan dengan jenis kelamin. Seringkali perempuan memiliki keterbatasan akses terhadap sumberdaya pendidikan dan pekerjaan.

Penelitian ini akan menganalisis perkembangan pengangguran di Indonesia serta karakteristik pengangguran terdidik menurut wilayah tempat tinggal dan jenis kelamin. Selain itu akan dilihat bagaimana penganggur terdidik dipengaruhi oleh berbagai variabel bebas. Variabel yang digunakan adalah tingkat kesempatan kerja, yaitu proporsi jumlah penduduk bekerja terhadap angkatan kerja (Badan Pusat Statistik Provinsi Jawa Barat, 2018). Tingkat kesempatan kerja penduduk terdidik adalah tingkat kesempatan kerja dari penduduk dengan pendidikan yang ditamatkan SMA ke atas. Kemudian tingkat kemiskinan yaitu persentase penduduk yang memiliki ketidakmampuan dari sisi ekonomi untuk memenuhi kebutuhan dasar makanan dan bukan makanan yang diukur dari sisi pengeluaran terhadap jumlah penduduk. Penduduk Miskin adalah penduduk yang memiliki rata-rata pengeluaran perkapita perbulan dibawah garis kemiskinan (Badan Pusat Statistik, 2018b).

Variabel lainnya adalah laju pertumbuhan ekonomi adalah perubahan produk domestik bruto atas dasar harga konstan suatu periode terhadap periode sebelumnya. Produk domestik bruto sendiri adalah jumlah nilai tambah yang dihasilkan oleh seluruh unit usaha dalam suatu negara tertentu, atau merupakan jumlah nilai barang dan jasa akhir yang dihasilkan oleh seluruh unit ekonomi. Variabel lainnya adalah rata-rata upah, dalam penelitian ini digunakan rata-rata Upah Minimum Provinsi sebagai angka upah nasional.

Penelitian ini dapat memberikan gambaran terkait perkembangan dan profil penduduk terdidik menurut jenis kegiatan di Indonesia, serta peran perempuan dalam dunia kerja dalam upaya mencapai target SDGs kedelapan. Penting diketahui gambaran informasi terkait bagaimana peran kerja penduduk terdidik, perempuan di Indonesia dalam aktivitas ketenagakerjaan dan ekonomi. Informasi mengenai tingkat partisipasi angkatan kerja serta pengangguran menurut jenis kelamin akan menghasilkan informasi mengenai kelompok-kelompok demografi spesifik tertentu yang harus diintervensi (International Labour Organization, 2008).

\section{METODE}

Pendekatan penelitian ini adalah pendekatan kuantitatif berdasarkan data sekunder. Data sekunder yang digunakan bersumber dari Badan Pusat Statistik (BPS). Sumber data yang digunakan adalah series tahun 2001 hingga 2018. Untuk data ketenagakerjaan, series 2001 hingga 2004 adalah data tahunan, sedangkan data sejak tahun 2005 adalah data semesteran, tahun 2005 menggunakan data bulan November, dan seterusnya menggunakan data bulan Agustus. Untuk data tingkat kemiskinan, seris data hingga tahun 2010 adalah data tahunan, sedangkan sejak 2011 terbit series 
secara semesteran, dalam penelitian ini data 2011 hingga 2018 yang digunakan adalah data bulan Maret.

Data pertumbuhan ekonomi yang digunakan adalah data tahunan, kecuali data tahun 2018 adalah angka pertumbuhan ekonomi adalah kumulatif hingga triwulan III 2018 (c to c). Data upah dalam penelitian ini adalah rata-rata Upah Minimum Provinsi (UMP). Adapun data kesempatan kerja yang digunakan bersumber dari Survei Angkatan kerja Nasional (Sakernas).

Penentuan variabel yang diduga memberikan pengaruh kuat terhadap pengangguran didasarkan pada ketersediaan data dan hasil penelitian-penelitian terdahulu, seperti (Fitri \& Junaidi, 2016) dan (Mada \& Ashar, 2015).

Teknik analisis data yang digunakan dalam penelitian ini adalah analisis deskriptif dan analisis statistik. Analisis deskriptif digunakan untuk mengetahui perkembangan serta profil ketenagakerjaan termasuk pengangguran dan pengangguran terdidik menurut karakteristik demografi di Indonesia. Adapun analisis statistik menggunakan metode analisis regresi linier berganda.

Persamaan pengaruh beberapa variabel makro terhadap pengangguran terdidik menggunakan regresi linier berganda (Sulistyono \& Sulistiyowati, 2017). Persamaannya dapat dinotasikan secara fungsional sebagai berikut :

Pengaruh laju pertumbuhan ekonomi, tingkat kesempatan kerja, rata-rata upah, tingkat kemiskinan, tingkat kesempatan kerja penduduk terdidik, jumlah penduduk miskin, dan jumlah penduduk usia kerja terhadap pengangguran terdidik:

$\mathrm{Y}=\beta_{0}+\beta_{1} \mathrm{X}_{1}+\beta_{2} \mathrm{X}_{2}+\beta_{3} \mathrm{X}_{3}+\beta_{4} \mathrm{X}_{4}+\beta_{5} \mathrm{X}_{5}$

$+\beta 6 \mathrm{X} 6+\beta_{7} \mathrm{X}_{7}+\mathrm{ui}$

Keterangan:

$\mathrm{Y}=$ Pengangguran terdidik

$\mathrm{X}_{1}=$ Laju pertumbuhan ekonomi

$\mathrm{X}_{2}=$ Tingkat kesempatan kerja

$\mathrm{X}_{3}=$ Rata-rata Upah

$\mathrm{X}_{4}=$ Tingkat Kemiskinan

$\mathrm{X}_{5}=$ Tingkat kesempatan kerja terdidik
$\mathrm{X} 6$ = Jumlah penduduk miskin

$\mathrm{X}_{7}=$ Jumlah penduduk usia kerja

$\beta o=$ Konstanta

$\beta 1=$ Koefisien regresi

Untuk melihat berpengaruh atau tidaknya variabel bebas terhadap variabel tak bebas, menggunakan selang kepercayaan $95 \%$ atau tingkat signifikansi $<5 \%$. Besarnya pengaruh dilihat dari koefisien determinasi $\left(\mathrm{R}^{2}\right)$. Pengolahan data menggunakan SPSS versi 21.

\section{HASIL DAN PEMBAHASAN}

Penduduk usia kerja di Indonesia selama kurun waktu 2001 hingga 2018 meningkat lebih dari 50 juta orang, dari 144,03 juta orang menjadi 194,78 juta orang di tahun 2018. Hal ini seiring dengan bertambahnya penduduk Indonesia. Demikan halnya dengan jumlah angkatan kerja dan penduduk bekerja, setiap tahunnya menunjukkan tren meningkat. Adapun jumlah penganggur mengalami penurunan, jika pada tahun 2001 sebanyak 8,o1 juta orang, pada tahun 2018 berkurang menjadi 7,oo juta orang.

Dalam satu dekade terakhir, secara umum jumlah penganggur di Indonesia menunjukkan tren menurun. Tahun 2001 jumlah penganggur mencapai 9,39 juta jiwa, dan Agustus 2018 berkurang hampir dua juta jiwa menjadi 7,oo juta jiwa. Penurunan ini diiringi dengan turunnya Tingkat Pengangguran Terbuka (TPT). Dari TPT 8,39\% di 2008, turun menjadi 5,34\% pada 2018 (Agustus). Rata-rata penurunan TPT pada periode ini mencapai $4 \%$ per tahun.

Berbeda dengan tren jumlah penganggur yang cenderung menurun, jumlah penduduk bekerja pada periode yang sama menunjukkan adanya peningkatan, kecuali di tahun 2011. Pada tahun 2011 jumlah penduduk bekerja turun menjadi 107,42 juta orang, dari sebelumnya 108,21 juta orang. Pada tahun 2018 (Agustus) jumlah penduduk bekerja telah mencapai 124 juta orang, dengan tingkat partisipasi angkatan kerja (TPAK) sebesar $67,26 \%$. Sejak tahun 2015, TPAK menunjukkan tren meningkat setiap tahunnya. 
JPPM (Jurnal Pendidikan dan Pemberdayaan Masyarakat), 5 (2), 2018 - 158 Isti Larasati Widiastuty

Tabel 1. Indikator Ketenagakerjaan Indonesia, 2001-2018

\begin{tabular}{lcccrrrr}
\hline Tahun & $\begin{array}{c}\text { Penduduk Usia } \\
\text { Kerja (Juta } \\
\text { Orang) }\end{array}$ & $\begin{array}{c}\text { Angkatan } \\
\text { Kerja (Juta } \\
\text { Orang) }\end{array}$ & $\begin{array}{c}\text { Bekerja } \\
\text { (Juta } \\
\text { Orang) }\end{array}$ & $\begin{array}{c}\text { Penganggur } \\
\text { (Juta Orang) }\end{array}$ & $\begin{array}{r}\text { TPAK } \\
(\%)\end{array}$ & $\begin{array}{r}\text { TKK } \\
(\%)\end{array}$ & $\begin{array}{r}\text { TPT } \\
(\%)\end{array}$ \\
\hline 2001 & 144,03 & 98,81 & 90,81 & 8,01 & 68,60 & 91,90 & 8,10 \\
2002 & 148,73 & 100,78 & 91,65 & 9,13 & 67,76 & 90,94 & 9,06 \\
2003 & 151,41 & 102,75 & 92,81 & 9,94 & 67,86 & 90,33 & 9,67 \\
2004 & 153,92 & 103,97 & 93,72 & 10,25 & 67,55 & 90,14 & 9,86 \\
2005 & 158,49 & 105,86 & 93,96 & 11,90 & 66,79 & 88,76 & 11,24 \\
2006 & 160,81 & 106,39 & 95,46 & 10,93 & 66,16 & 89,72 & 10,28 \\
2007 & 164,12 & 109,94 & 99,93 & 10,01 & 66,99 & 90,89 & 9,11 \\
2008 & 166,64 & 111,95 & 102,55 & 9,39 & 67,18 & 91,61 & 8,39 \\
2009 & 169,33 & 113,83 & 104,87 & 8,96 & 67,23 & 92,13 & 7,87 \\
2010 & 172,07 & 116,53 & 108,21 & 8,32 & 67,72 & 92,86 & 7,14 \\
2011 & 173,85 & 116,10 & 107,42 & 8,68 & 66,78 & 92,52 & 7,48 \\
2012 & 176,87 & 119,85 & 112,50 & 7,34 & 67,76 & 93,87 & 6,13 \\
2013 & 179,97 & 120,17 & 112,76 & 7,41 & 66,77 & 93,83 & 6,17 \\
2014 & 182,99 & 121,87 & 114,63 & 7,24 & 66,60 & 94,06 & 5,94 \\
2015 & 186,10 & 122,38 & 114,82 & 7,56 & 65,76 & 93,82 & 6,18 \\
2016 & 189,10 & 125,44 & 118,41 & 7,03 & 66,34 & 94,39 & 5,61 \\
2017 & 192,08 & 128,06 & 121,02 & 7,04 & 66,67 & 94,50 & 5,50 \\
2018 & 194,78 & 131,01 & 124,00 & 7,00 & 67,26 & 94,66 & 5,34 \\
\hline$(B a d a n$ & & & & & & &
\end{tabular}

(Badan Pusat Statistik, 2018b)

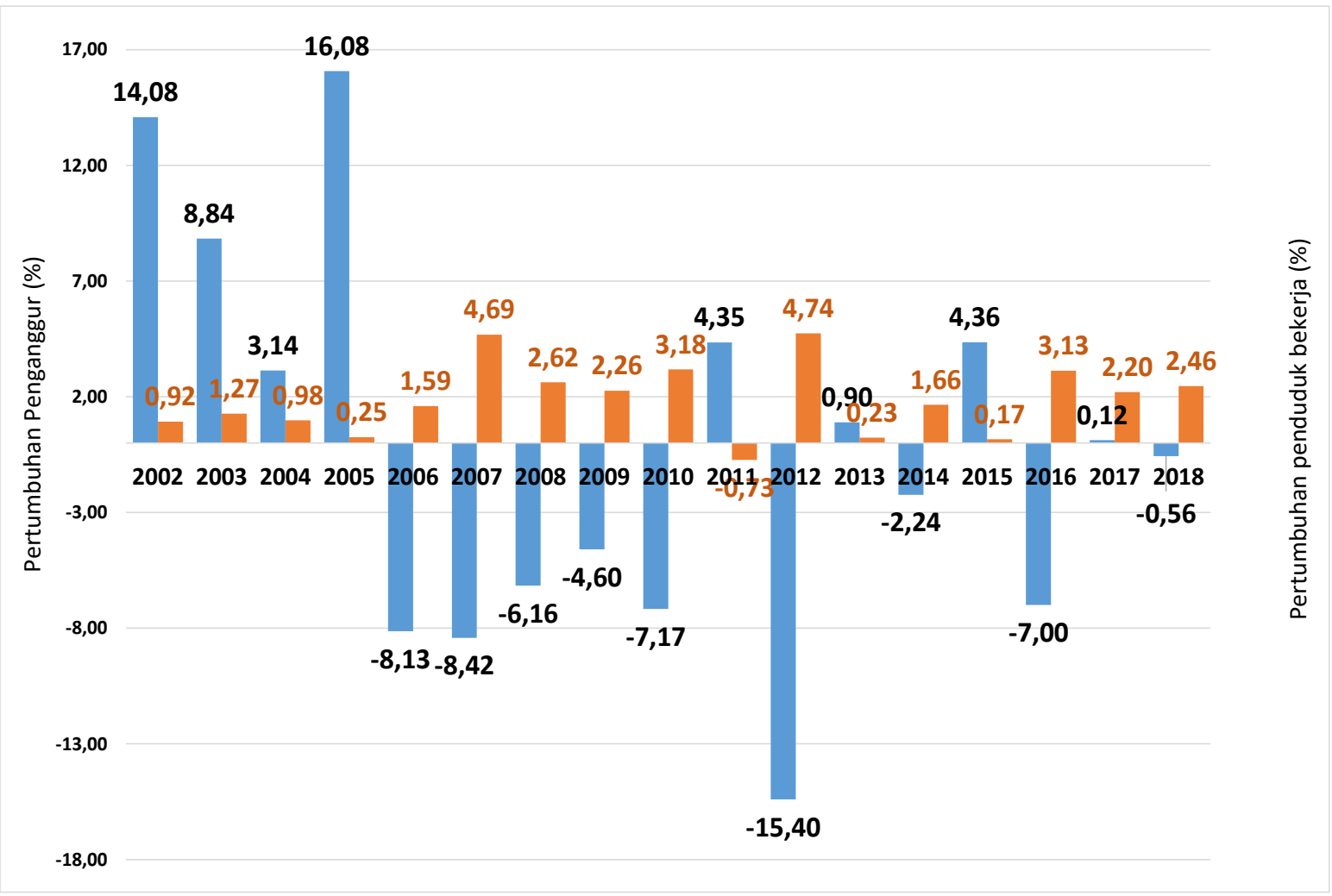

Gambar 1. Pertumbuhan Jumlah Penduduk Bekerja dan Penganggur di Indonesia, 2002-2018 (\%)

Adapun pertumbuhan jumlah penduduk bekerja dan penganggur dapat dilihat pada Gambar 1. Gambar 1 memperlihatkan adalanya ketidakselarasan antara pertum- buhan kedua variabel ini pada beberapa tahun pengamatan. Pada beberapa tahun pertumbuhan penganggur lebih tinggi dibandingkan dengan pertumbuhan penduduk 
bekerja. Peningkatan jumlah penganggur tertinggi terjadi pada tahun 2005, dimana pertumbuhannya mencapai $16,08 \%$. Adapun penurunan terendah terjadi pada tahun 2012, yaitu minus $15,40 \%$. Kondisi penduduk bekerja dan penganggur di Indonesia, menunjukkan pertumbuhan yang berfluktuasi setiap tahunnya.

Data ketenagakerjaan menurut wilayah tempat tinggal, yaitu perkotaan dan perdesaan menunjukkan adanya perbedaan. Penduduk yang bekerja di perkotaan semakin meningkat setiap tahunnya. Jika pada tahun 2014 penduduk bekerja di perkotaan lebih banyak daripada perdesaan, maka sejak tahun 2015 menunjukkan hal sebaliknya. Demikian halnya dengan jumlah penganggur. Penganggur di perkotaan hampir dua kali dari penganggur di perdesaan. Demikian halnya TPT di perkotaan lebih tinggi dibandingkan di perdesaan. Tabel 2 juga menunjukkan tingkat kesempatan kerja di perdesaan lebih besar dibandingkan di perkotaan. Secara total di tahun 2018 tingkat kesempatan kerja (TKK) di Indonesia mencapai 94,66\%, dan 96,00\% kesempatan kerja terdapat di perdesaan.

Jika dirinci menurut jenis kelamin, maka terlihat perbedaan nyata antara lakilaki dan perempuan. Tabel 3 menunjukkan bahwa tingkat partisipasi angkatan kerja (TPAK) perempuan hampir setengah lakilaki. Di tahun 2018, TPAK perempuan sebesar 55,04\%, sedangkan laki-laki mencapai $83,05 \%$. Artinya penduduk laki-laki pada usia kerja yang bekerja lebih banyak hampir dua kali dibandingkan penduduk perempuan pada usia kerja yang bekerja. Adapun tingkat pengangguran terbuka (TPT) antara laki-laki dan perempuan relatif sama.

Tabel 2. Indikator Ketenagakerjaan Indonesia Menurut Wilayah Tempat Tinggal, 2014-2018

\begin{tabular}{|c|c|c|c|c|c|c|}
\hline Indikator & & 2014 & 2015 & 2016 & 2017 & 2018 \\
\hline \multirow{2}{*}{ Bekerja (Juta Orang) } & Perkotaan & 55,64 & 59,31 & 61,48 & 63,92 & 66,26 \\
\hline & Perdesaan & 58,98 & 55,51 & 56,93 & 57,10 & 57,74 \\
\hline \multirow{2}{*}{ Penganggur (Juta Orang) } & Perkotaan & 4,26 & 4,68 & 4,34 & 4,65 & 4,57 \\
\hline & Perdesaan & 2,98 & 2,88 & 2,69 & 2,39 & 2,43 \\
\hline \multirow{2}{*}{ ТРАК (\%) } & Perkotaan & 64,47 & 63,88 & 66,16 & 63,94 & 66,33 \\
\hline & Perdesaan & 68,80 & 67,95 & 70,32 & 69,21 & 72,32 \\
\hline \multirow{2}{*}{ ТРТ (\%) } & Perkotaan & 7,12 & 7,31 & 6,53 & 6,60 & 6,50 \\
\hline & Perdesaan & 4,81 & 4,93 & 4,35 & 4,51 & 4,00 \\
\hline \multirow{2}{*}{ TKK (\%) } & Perkotaan & 92,88 & 92,69 & 93,47 & 93,40 & 93,50 \\
\hline & Perdesaan & 95,19 & 95,07 & 95,65 & 95,49 & 96,00 \\
\hline
\end{tabular}

(Badan Pusat Statistik, 2018b)

Tabel 3. Indikator Ketenagakerjaan Indonesia Menurut Jenis Kelamin, 2014-2018

\begin{tabular}{|c|c|c|c|c|c|c|}
\hline Indikator & & 2014 & 2015 & 2016 & 2017 & 2018 \\
\hline \multirow{2}{*}{ Bekerja (Juta Orang) } & Laki-laki & 71,46 & 72,15 & 72,94 & 74,74 & 76,06 \\
\hline & Perempuan & 43,16 & 42,67 & 45,47 & 46,29 & 47,95 \\
\hline \multirow{2}{*}{ Penganggur (Juta Orang) } & Laki-laki & 4,36 & 4,66 & 4,41 & 4,38 & 4,34 \\
\hline & Perempuan & 2,88 & 2,90 & 2,62 & 2,67 & 2,66 \\
\hline \multirow{2}{*}{ ТРАК (\%) } & Laki-laki & 83,05 & 82,71 & 83,46 & 81,97 & 83,05 \\
\hline & Perempuan & 50,22 & 48,87 & 52,71 & 50,77 & 55,04 \\
\hline \multirow{2}{*}{ ТPТ (\%) } & Laki-laki & 5,75 & 6,07 & 5,66 & 5,70 & 5,36 \\
\hline & Perempuan & 6,26 & 6,37 & 5,26 & 5,45 & 5,27 \\
\hline \multirow{2}{*}{ TKK (\%) } & Laki-laki & 94,25 & 93,93 & 94,34 & 94,30 & 94,64 \\
\hline & Perempuan & 93,74 & 93,63 & 94,74 & 94,55 & 94,73 \\
\hline
\end{tabular}

(Badan Pusat Statistik, 2018b) 
JPPM (Jurnal Pendidikan dan Pemberdayaan Masyarakat), 5 (2), 2018 - 160

Isti Larasati Widiastuty

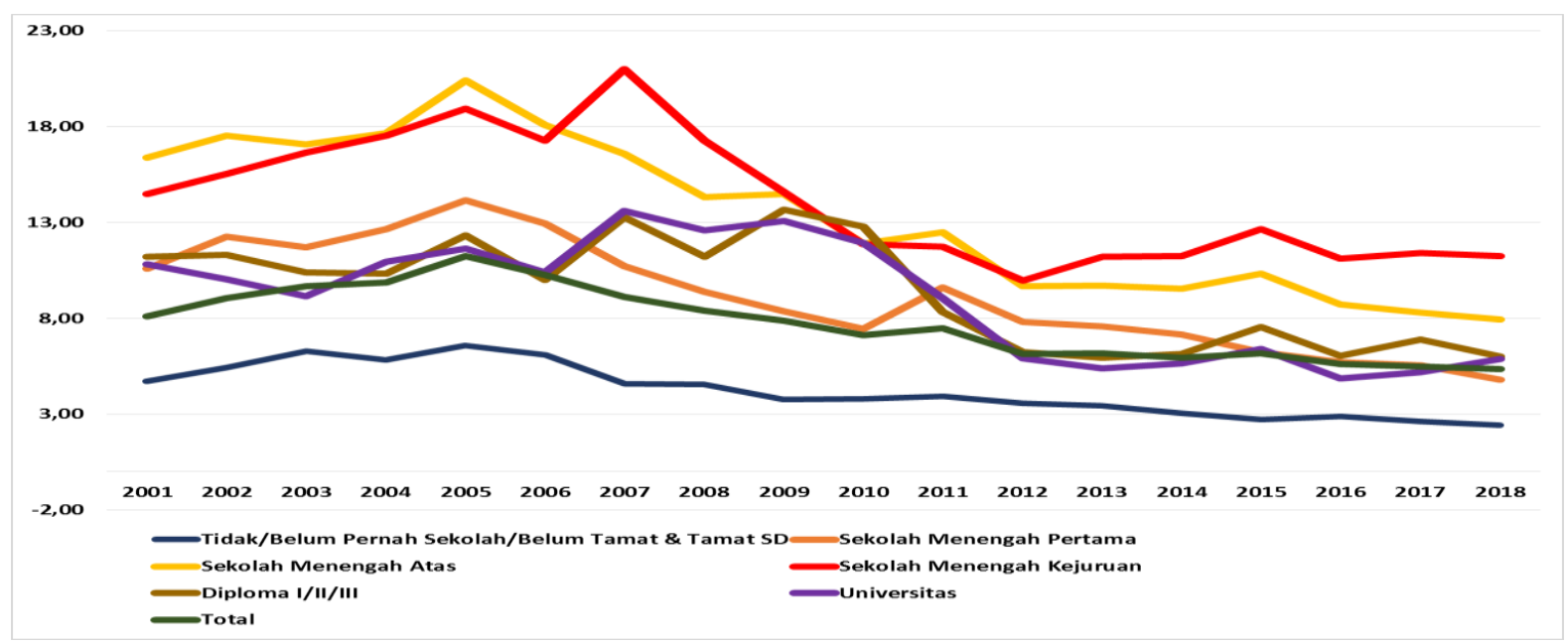

Gambar 2. TPT Menurut Tingkat Pendidikan, 2008-2018

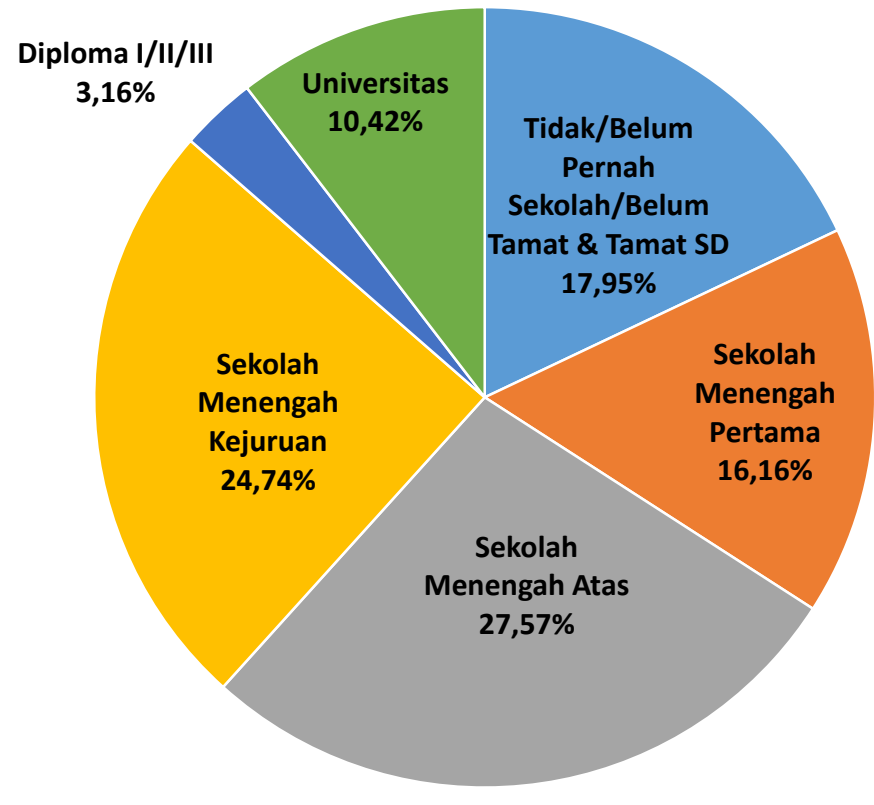

Gambar 3. Struktur Pendidikan Penganggur di Indonesia, Agustus 2018

Gambar 2 menunjukkan TPT menurut jenjang pendidikan terakhir yang ditamatkan. Pada periode 2001 hingga 2018 TPT menurut jenjang pendidikan memiliki kecenderungan menurun, sejalan dengan TPT total. Selama rentang waktu terlihat bahwa TPT dari pendidikan SMA dan SMK selalu lebih tinggi dibandingkan dengan jenjang lainnya. TPT SMK pernah mencapai level tertinggi di tahun 2007, yaitu mencapai $21 \%$. Artinya jumlah penduduk usia 15 tahun ke atas yang menganggur hampir seperempat dari total angkatan kerja. Di tahun 2018 TPT pendidikan SMK mencapai 11,24\%, sedangkan SMA sebesar 7,95\%. Secara jumlah, penganggur berpendidikan SMA dan SMK pun lebih dari setengah total penganggur di Indonesia (52,31\%). Tingginya TPT SMA dan SMK sebanding dengan besarnya kontribusi terhadap total penganggur. Adapun TPT untuk jenjang pendidikan tidak/belum pernah sekolah/belum tamat dan tamat SD, selama kurun waktu 21 tahun selalu rendah, lebih rendah dari rata-rata TPT total.

Selanjutnya Gambar 3 menunjukkan struktur pendidikan dari penganggur di Indonesia pada kondisi Agustus 2018. Terlihat bahwa persentase penganggur terdidik terhadap total penganggur di Indonesia pada Agustus 2018 mencapai 65,89\%. Proporsi ini tidak jauh berbeda dengan struktur pendidik- 
an penganggur di Indonesia pada tahun sebelumnya.

Persentase penganggur dengan pendidikan SMP ke bawah mencapai 34,11\%. Series data menunjukkan bahwa untuk jenjang pendidikan rendah, tingkat pengangguran cenderung menurun. Kondisi ini memberikan indikasi bahwa angkatan kerja dengan jenjang pendidikan SMP ke bawah lebih mudah terserap dalam dunia kerja.

Rata-rata upah buruh per bulan yang dihitung berdasarkan data Survei Angkatan Kerja Nasional (Badan Pusat Statistik, 2018a) ditunjukkan dalam gambar 5. Rata-rata upah buruh per bulan Indonesia di tahun 2018 mencapai 2,83 juta rupiah per orang. Pada Agustus 2018, ada tiga pulau yang memiliki rata-rata upah buruh di atas nasional, dan tiga pulau lainnya di bawah angka rata-rata nasional. Rata-rata upah buruh tertinggi ada di Pulau Maluku dan Papua, sedangkan terendah di Pulau Bali dan Nusa Tenggara.

Tabel 4 menunjukkan semakin tinggi jenjang pendidikan yang ditamatkan, jumlah
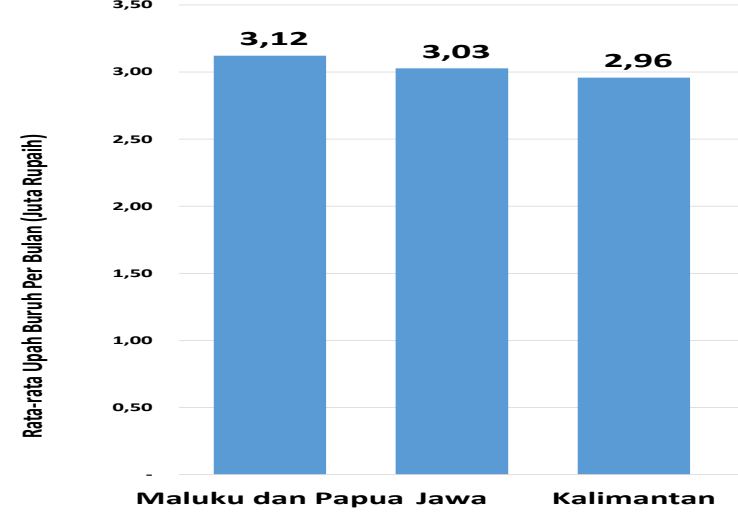

penduduk bekerja di perkotaan lebih besar dibandingkan di perdesaan. Terlihat pada tahun 2018 penduduk bekerja dengan tingkat pendidikan Universitas di perkotaan mencapai 8,85 juta orang, sedangkan di perdesaan hanya sebanyak 2,86 juta orang. Sebaliknya untuk jenjang pendidikan yang ditamatkan SD ke bawah, lebih banyak di perdesaan. Adapun untuk indikator lainnya relatif seimbang. Jika dirinci menurut jenis kelamin maka terlihat perbedaan nyata pada indikator tingkat partisipasi angkatan kerja (TPAK). TPAK laki-laki secara total sebesar 82,69\%, sedangkan perempuan hanya $51,88 \%$. Walaupun demikian partisipasi perempuan dalam pekerjaan di ranah publik menunjukkan tren meningkat. Hal ini sejalan dengan penelitian Momsen, dimana seiring dengan perkembangan industrialisasi terutama di perkotaan, maka kegiatan industri telah mendorong perempuan untuk terlibat sebagai tenaga kerja dalam industri (Momsen, 2013).

Gambar 4. Rata-rata Upah Buruh per Bulan di Indonesia, Agustus 2018

Tabel 4. Indikator Ketenagakerjaan Indonesia Menurut Pendidikan dan Wilayah Tempat Tinggal, 2018

\begin{tabular}{rlrrrrrrr}
\hline Wilayah & & $\leq$ SD & SMP & \multicolumn{1}{c}{ SMA } & \multicolumn{1}{c}{ SMK } & Diploma & Univ & Total \\
\hline \multirow{5}{*}{ Perkotaan } & Bekerja (Juta Orang) & 19,61 & 11,62 & 13,95 & 10,73 & 2,70 & 8,85 & 67,46 \\
& Pengangguran (Juta Orang) & 0,67 & 0,65 & 1,22 & 1,29 & 0,17 & 0,57 & 4,57 \\
& TPAK (\%) & 62,22 & 51,98 & 65,44 & 75,49 & 74,44 & 82,54 & 65,21 \\
& TPT (\%) & 3,49 & 5,38 & 7,78 & 11,26 & 6,05 & 5,95 & 6,45 \\
& TKK (\%) & 96,51 & 94,62 & 92,22 & 88,74 & 93,95 & 94,05 & 93,55 \\
\hline \multirow{5}{*}{ Perdesaaan } & Bekerja (Juta Orang) & 33,50 & 11,26 & 7,37 & 3,81 & 0,80 & 2,86 & 59,61 \\
& Pengangguran (Juta Orang) & 0,58 & 0,49 & 0,71 & 0,44 & 0,05 & 0,16 & 2,43 \\
& TPAK (\%) & 70,97 & 59,22 & 73,69 & 77,87 & 81,94 & 87,89 & 69,84 \\
& TPT (\%) & 1,80 & 4,20 & 8,28 & 11,18 & 5,92 & 5,70 & 4,04 \\
& TKK (\%) & 98,20 & 95,80 & 91,72 & 88,82 & 94,08 & 94,30 & 95,96 \\
\hline
\end{tabular}

(Badan Pusat Statistik, 2018b)
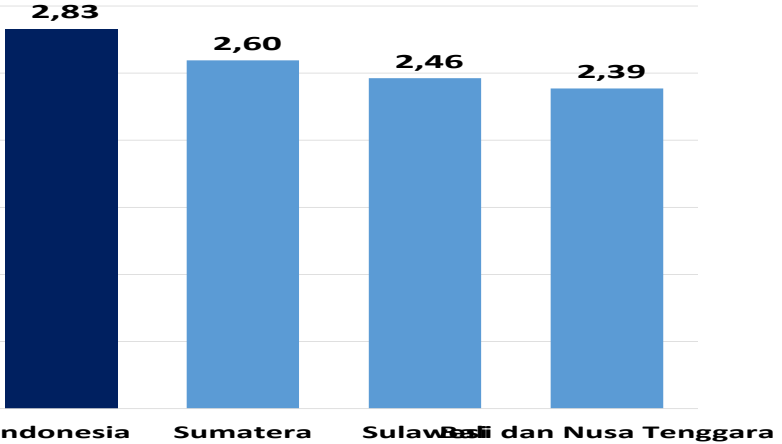
Pada seluruh jenjang pendidikan yang ditamatkan, partisipasi kerja laki-laki lebih tinggi dibandingkan perempuan, sebagaimana penelitian terdahulu (Widodo, 2006). Hal ini mengindikasikan bahwa perempuan lebih sedikit yang terlibat dalam kerja di ranah publik. Penelitian lain menunjukkan dari sudut pandang peran antara laki-laki dan perempuan, keduanya sama-sama melaksanakan peran dalam ranah domestik, publik, dan sosial, namun dalam kenyataannya, peran domestik lebih banyak ditanggung oleh perempuan (Intan, 2014).

Indikator ketenagakerjaan yang dirinci menurut pulau di Indonesia, menunjukkan beberapa capaian tertinggi indikator terdapat di Pulau Jawa. Pada kondisi Agustus 2018, tingkat partisipasi angkatan kerja terbesar berada di Pulau Bali dan Nusa Tenggara, mencapai $69,00 \%$. Adapun yang terendah di Pulau Sulawesi $(62,44 \%)$. Jika dibandingkan dengan partisipasi secara nasional, maka hanya ada dua pulau yang capaian TPAKnya di atas nasional, yaitu Bali dan Nusa Tenggara (69,00\%), serta Maluku dan Papua (68,10\%).

Hal berbeda dari partisipasi angkatan kerja ditunjukkan oleh tingkat pengangguran terbuka (TPT) di Sumatera dan Jawa capaiannya di atas rata-rata nasional. Pada Agustus 2018, TPT tertinggi di Pulau Jawa sebesar 5,86\%. Adapun TPT terendah dicapai Pulau Bali dan Nusa Tenggara sebesar 2,66\%. Kondisi ini menunjukkan tingkat kesempatan kerja (TKK) di Pulau Jawa paling rendah dibandingkan pulau lainnya. Namun sampai saat ini Pulau Jawa masih menjadi primadona bagi para pencari kerja. Tingkat urbanisasi ke Jawa pun terus bertambah. Tampak nyata bahwa tingkat urbanisasi di Pulau Jawa jauh lebih tinggi dibandingkan dengan luar Pulau Jawa (Tjiptoherijanto, 1999).

Penduduk yang terdidik, sebagaimana dijelaskan sebelumnya sebagai penduduk dengan tingkat pendidikan terakhir yang ditamatkan SMA ke atas, memiliki TPT lebih tinggi dari rata-rata TPT nasional. Kondisi ini terjadi pada wilayah perkotaan dan perdesaan, juga pada jenis kelamin laki-laki dan perempuan. Tergambar bahwa tidak ada perbedaan nyata tingkat pengangguran terbuka laki-laki dan perempuan pada jenjang pendidikan tinggi. Pada kondisi Agustus 2018, TPT penduduk terdidik lebih tinggi dibandingkan yang lainnya.

Tabel 5. Indikator Ketenagakerjaan Indonesia Menurut Pendidikan dan Jenis Kelamin, 2018

\begin{tabular}{rlrrrrrrr}
\hline Jenis Kelamin & SSD & SMP & SMA & SMK & Diploma & Univ & Total \\
\hline \multirow{5}{*}{ Laki-laki } & Bekerja (Juta Orang) & 30,22 & 14,14 & 13,86 & 9,86 & 1,59 & 6,29 & 75,96 \\
& Pengangguran (Juta Orang) & $\mathbf{0 , 8 3}$ & $\mathbf{0 , 7 5}$ & $\mathbf{1 , 1 4}$ & $\mathbf{1 , 1 7}$ & $\mathbf{0 , 1 0}$ & $\mathbf{0 , 3 5}$ & 4,34 \\
& TPAK (\%) & 85,32 & 70,75 & 84,75 & 88,29 & 86,57 & 89,11 & 82,69 \\
& TPT (\%) & $\mathbf{2 , 7 2}$ & 4,93 & 7,18 & $\mathbf{1 1 , 0 4}$ & 6,02 & 5,31 & 5,40 \\
& TKK (\%) & 97,28 & 95,07 & 92,82 & 88,96 & 93,98 & 94,69 & 94,60 \\
\hline \multirow{5}{*}{ Perempuan } & Bekerja (Juta Orang) & $\mathbf{2 2 , 9 0}$ & 8,74 & 7,46 & 4,68 & 1,91 & 5,42 & 51,11 \\
& Pengangguran (Juta Orang) & $\mathbf{0 , 4 3}$ & $\mathbf{0 , 3 9}$ & $\mathbf{0 , 7 9}$ & $\mathbf{0 , 5 7}$ & $\mathbf{0 , 1 2}$ & $\mathbf{0 , 3 8}$ & $\mathbf{2 , 6 6}$ \\
& TPAK (\%) & 51,86 & 39,78 & 49,51 & 58,49 & 68,56 & 78,29 & 51,88 \\
& TPT (\%) & $\mathbf{2 , 0 1}$ & 4,57 & 9,45 & 11,67 & 6,01 & 6,55 & 5,26 \\
& TKK (\%) & 97,99 & 95,43 & 90,55 & 88,33 & 93,99 & 93,45 & 94,74 \\
\hline
\end{tabular}

(Badan Pusat Statistik, 2018b)

Tabel 6. TPAK, TPT, dan TKK Menurut Pulau di Indonesia, Agustus 2018

\begin{tabular}{lccc}
\hline Pulau & TPAK & TPT & TKK \\
\hline Sumatera & 65,03 & 5,10 & 94,90 \\
Jawa & 62,49 & 5,86 & 94,14 \\
Bali \& Nusatenggara & 69,00 & 2,66 & 97,34 \\
Kalimantan & 65,12 & 4,83 & 95,17 \\
Sulawesi & 62,44 & 4,70 & 95,30 \\
Maluku \& Papua & 68,10 & 4,68 & 95,32 \\
Indonesia & 67,26 & 5,34 & 94,66 \\
\hline
\end{tabular}

(Badan Pusat Statistik, 2018b) 
Penduduk terdidik yang bekerja di perkotaan lebih banyak 2,4 kali dibandingkan di perdesaan. Adapun untuk penduduk terdidik laki-laki yang bekerja lebih banyak 1,6 kali dibanding perempuan. Demikian halnya untuk TPAK. Partisipasi angkatan kerja perempuan terdidik juga lebih rendah dibandingkan laki-laki. Kondisi ini semakin mengkonfirmasi bahwa peran perempuan dalam dunia kerja masih lebih rendah dibandingkan laki-laki.

Walaupun peran perempuan dalam aktivitas kerja masih lebih rendah, sumbangan pendapatan perempuan terhadap ekonomi menunjukkan adanya peningkatan setiap tahunnya. Data BPS terkait gender menunjukkan pada tahun 2010 perempuan hanya menyumbang sebesar $33,50 \%$ pendapatan. Kemudian meningkat menjadi $36,62 \%$ di tahun 2018. Pertumbuhan sumbangan pendapatan perempuan di Indonesia setiap tahunnya relatif rendah, walaupun lebih tinggi dibandingkan pertumbuhan capaian pembangunan gender. Indeks Pembangunan Gender di tahun 2010 sebesar 89,42 dan meningkat menjadi 90,96 di tahun 2018, dengan, rata-rata pertumbuhan dari 2010 hingga 2018 sebesar $0,24 \%$.

\section{Penganggur Terdidik dan Variabel yang Mempengaruhi}

Hasil pengolahan data menggunakan SPSS 21, diperoleh estimasi model secara simultan laju pertumbuhan ekonomi, tingkat kesempatan kerja, rata-rata upah, tingkat kemiskinan, tingkat kesempatan kerja penduduk terdidik, jumlah penduduk miskin, dan jumlah penduduk usia kerja memberikan pengaruh signifikan terhadap penganggur terdidik. Nilai koefisien determinasi atau $\mathrm{R}^{2}$ sebesar 0,959, artinya $95,90 \%$ variabelvariabel bebas tersebut dapat menjelaskan penganggur terdidik secara sangat signifikan. Adapun sisanya sebesar 4,10\% dijelaskan oleh variabel di luar model. Kondisi ini sejalan dengan hasil penelitian Junaidi yang menyatakan bahwa secara simultan, pendidikan, upah dan kesempatan kerja mempunyai pengaruh yang signifikan terhadap penganggur terdidik. Namun secara parsial, kesempatan Kerja berpengaruh negatif terhadap penganggur terdidik di Provinsi Jambi (Fitri \& Junaidi, 2016). Demikian halnya Mankiw dalam bukunya "Teori Makro Ekonomi" (Mankiw, 2003, p. 140) menyatakan bahwa upah merupakan salah satu faktor yang mempengaruhi tingkat pengangguran.

Adapun jika dilihat secara parsial, laju pertumbuhan ekonomi dan tingkat kesempatan kerja total tidak signifikan mempengaruhi penganggur terdidik. Model yang dihasilkan adalah

$\mathrm{Y}=21.214,138-0,001 \mathrm{X}_{3}-713,108 \mathrm{X}_{4}-368,736$ $\mathrm{X}_{5}+339,093 \mathrm{X} 6+86,518 \mathrm{X}_{7}+$ ui

Persamaan ini menunjukkan jika ratarata upah, tingkat kemiskian, dan tingkat kesempatan kerja terdidik memiliki korelasi negatif dengan penganggur terdidik. Setiap peningkatan 1.000 rupiah upah akan mengurangi jumlah penganggur terdidik sebanyak 1 orang. Kemudian jika terjadi peningkatan $1 \%$ tingkat kemiskinan akan menurunkan penganggur terdidik sebanyak 713 orang. Demikian juga jika terjadi peningkatan tingkat kesempatan terdidik, akan menurunkan penganggur terdidik sebanyak 369 orang. Adapun untuk variabel jumlah penduduk miskin dan jumlah penduduk usia kerja memiliki korelasi positif. Artinya, setiap peningkatan 1 orang miskin akan menurunkan penganggur terdidik sebanyak 339 orang. Demikian halnya untuk variabel penduduk usia kerja, jika terdapat penambahan 1 orang penduduk usia kerja, maka akan meningkatkan sebanyak 87 orang penganggur terdidik.

Adanya hubungan penganggur terdidik dengan beberapa variabel makro ekonomi kiranya harus tetap menjadi perhatian stakeholders. Relevan dengan penelitian Okun, Fellner, \& Greenspan (1973, p. 208) yang menyatakan bahwa ...high-quality workers avoiding unemployment by accepting lowquality and less productive jobs..." 
JPPM (Jurnal Pendidikan dan Pemberdayaan Masyarakat), 5 (2), 2018 - 164

Isti Larasati Widiastuty

Tabel 6. Indikator Penduduk Terdidik Menurut Kegiatan, Wilayah Tempat Tinggal dan Jenis Kelamin, 2018

\begin{tabular}{lrrrr}
\hline \multirow{2}{*}{ Indikator } & \multicolumn{3}{c}{ Wilayah Tempat Tinggal } & \multicolumn{2}{c}{ Jenis Kelamin } \\
\cline { 2 - 5 } & Perkotaan & Perdesaan & Laki-laki & Perempuan \\
\hline Bekerja (Juta Orang) & 36,23 & 14,85 & 31,60 & 19,47 \\
Pengangguran (Juta Orang) & 3,25 & 1,36 & 2,76 & 1,85 \\
TPAK (\%) & 66,38 & 70,98 & 78,66 & 55,14 \\
TPT (\%) & 8,22 & 8,41 & 7,94 & 8,84 \\
TKK (\%) & 91,78 & 91,59 & 92,06 & 91,16 \\
\hline
\end{tabular}

(Badan Pusat Statistik, 2018b)

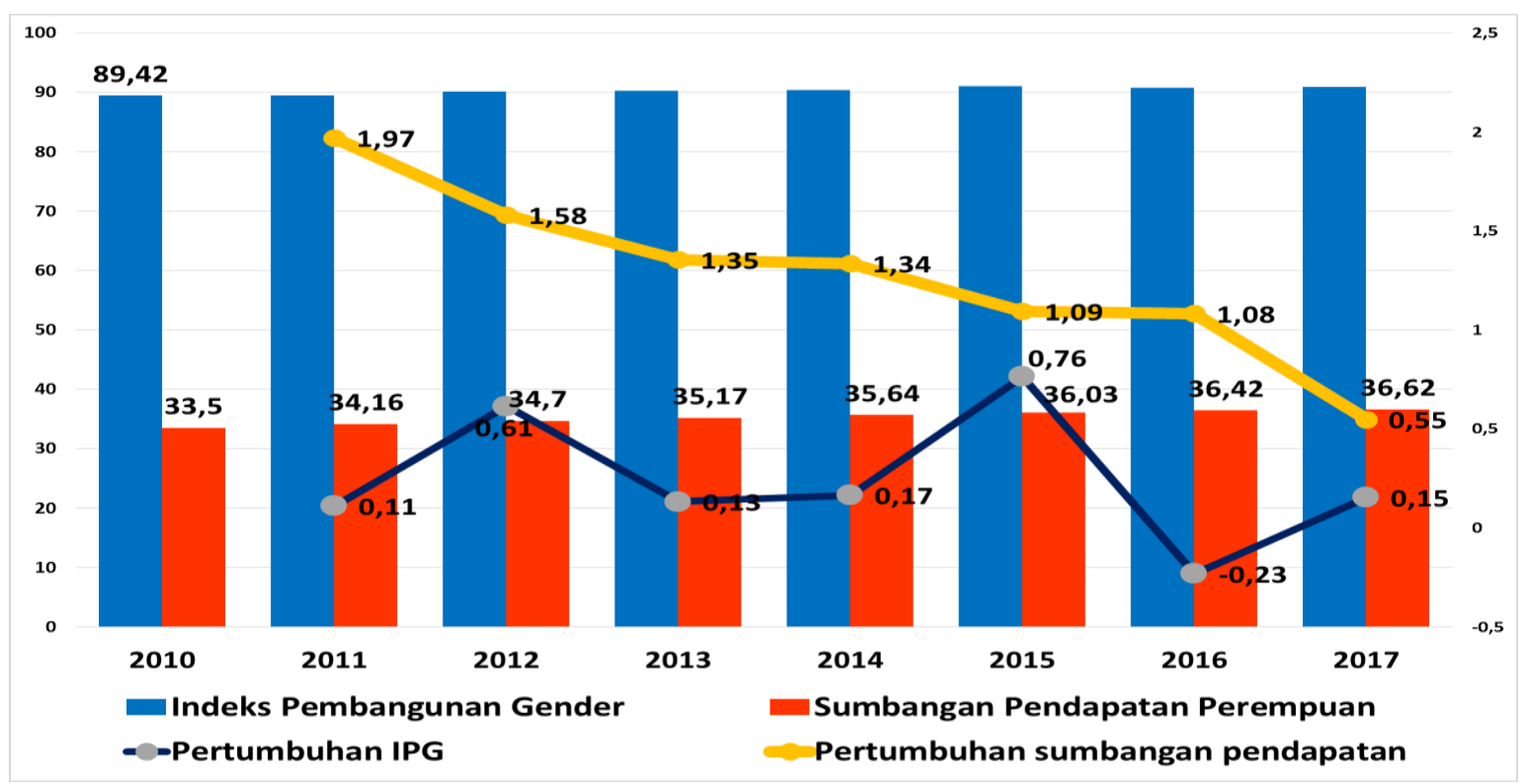

Gambar 5. Indeks Pembangunan Gender, Sumbangan Pendapatan Perempuan dan Pertumbuhannya di Indonesia, 2010-2017

Penduduk dengan tingkat pendidikan di atas SMA ini akan melakukan pekerjaan di bawah jenjangnya sebagai upaya bertahan hidup dan menghindari sebagai seorang penganggur. Penduduk terdidik termasuk di dalamnya adalah perempuan terdidik, memiliki peran tinggi dalam kerja di Indonesia. Walaupun tingkat pengangguran dari kelompok ini tertinggi dibandingkan pendidikan di bawahnya, namun kontribusinya sebagai pekerja tidak kalah besar.

Dalam upaya percepatan mencapai target pertumbuhan ekonomi inklusif melalui pemerataan kesempatan kerja dan ekonomi layak untuk semua adalah bagaimana membangkitkan pemberdayaan masyarakat di berbagai sektor. Penelitian terdahulu menyebutkan dalam upaya peningkatan kualitas pendidikan untuk target SDGs adalah melalui pemberdayaan masyarakat (Annur, Wati, Mahtari, \& Prastika, 2018).

\section{SIMPULAN}

Tren penduduk usia kerja, penduduk bekerja, tingkat partisipasi angkatan kerja, dan tingkat kesempatan kerja selama periode 2001 hingga 2018 menunjukkan peningkatan. Adapun tingkat pengangguran terbuka cenderung menurun. Selama kurun waktu 2001 hingga 2018 TPK dari pendidikan SMA dan SMK selalu jauh di atas rata-rata. Masih terdapat perbedaan nyata antara partisipasi perempuan dan laki-laki dalam dunia kerja. Partisipasi angkatan kerja perempuan masih rendah, baik di perkotaan maupun di perdesaan. Partisipasi angkatan kerja perempuan terdidik pun lebih rendah dibandingkan partisipasi kerja laki-laki terdidik, baik di perkotaan maupun perdesaan. Pengangguran terdidik memiliki hubungan sangat kuat secara simultan dengan laju pertumbuhan ekonomi, tingkat kesempatan kerja total, rata-rata upah, tingkat kemiskinan, tingkat 
kesempatan kerja terdidik, jumlah penduduk miskin, dan jumlah penduduk usia kerja. Namun secara parsial laju pertumbuhan ekonomi dan tingkat kesempatan kerja total tidak berkorelasi dengan pengangguran terdidik.

Informasi yang dihasilkan memberikan gambaran jika peran perempuan dalam aktivitas kerja masih lebih rendah dibandingkan laki-laki. Namun penduduk perempuan terdidik secara jumlah tidak jauh berbeda dari laki-laki. Perlu upaya komprehensif bagaimana meningkatkan peran perempuan dalam pembangunan, dengan tanpa mengesampingkan peran kerja perempuan lainnya, baik di ranah domestik, publik, maupun sosial. Partisipasi dan pemberdayaan perempuan menjadi salah satu kunci agar pertumbuhan ekonomi inklusif, kesempatan kerja dan ekonomi layak dapat dinikmati juga oleh perempuan Indonesia.

\section{DAFTAR PUSTAKA}

Annur, S., Wati, M., Mahtari, S., \& Prastika, M. D. (2018). Sustainable development goals (SDGs) dan peningkatan kualitas pendidikan. In Seminar Nasional Pendidikan (pp. 251-255). Banjarmasin.

Badan Pusat Statistik. (2008). Analisis pengangguran terdidik.

Badan Pusat Statistik. (2018a). Berita Resmi Statistik Keadaan Ketenagakerjaan Indonesia Agustus 2018.

Badan Pusat Statistik. (2018b). Tenaga kerja. Retrieved from https://www.bps.go.id/subject/6/tenag a-kerja.html\#subjekViewTabı

Badan Pusat Statistik Provinsi Jawa Barat. (2018). Keadaan angkatan kerja di Provinsi Jawa Barat Agustus 2017. Retrieved from https://jabar.bps.go.id/publication/2018 /02/23/26933c26d8d37f4fbicdcd52/kead aan-angkatan-kerja-di-provinsi-jawabarat-agustus-2017.html

Cutler, D. M., \& Katz, L. F. (1991). Macroeconomic performance and the disadvantaged. Brookings Papers on Economic Activity, (2), 1-74. https://doi.org/10.2307/2534589
Fitri, F., \& Junaidi, J. (2016). Pengaruh pendidikan, upah dan kesempatan kerja terhadap pengangguran terdidik di Provinsi Jambi. E-Jurnal Ekonomi Sumberdaya Dan Lingkungan, 5(1), 2632. https://doi.org/10.1111/j.14677652.2004.00085.x

Intan, S. (2014). Kedudukan perempuan dalam domestik dan publik perspektif jender (Suatu analisis berdasarkan normatifisme Islam). JPP (Jurnal Politik Profetik), 2(1). https://doi.org/10.24252/jpp.v2i1.957

International Labour Organization. (2008). Tren ketenagakerjaan dan sosial di Indonesia 2008: Kemajuan dan jalan menuju pembangunan padat karya. Jakarta. Retrieved from https://www.ilo.org/jakarta/whatwedo/ publications/WCMS_116210/lang-en/index.htm

International Labour Organization. (2013). 19 th International Conference of Labour Statisticians. Geneva. Retrieved from https://www.ilo.org/global/statisticsand-databases/meetings-andevents/international-conference-oflabour-statisticians/19/lang-en/index.htm

Jubaedah, Y., Rohaeni, N., \& Tati, T. (2015). Model link and match dengan pendekatan competency based training pada pembelajaran tata graha di sekolah menengah kejuruan. Jurnal Penelitian Pendidikan, 15(1), 19-26. Retrieved from http://ejournal.upi.edu/index.php/JER/ article/view/1281

Klasen, S. (2010). Measuring and monitoring inclusive growth: Multiple definitions, open questions, and some constructive proposals (No. 12). ADB Sustainable Development Working Paper Series. Manila. Retrieved from http://hdl.handle.net/11540/1404

Mada, M., \& Ashar, K. (2015). Analisis variabel yang mempengaruhi jumlah pengangguran terdidik di Indonesia. Jurnal Ilmu Ekonomi Dan Pembangunan, 15(1), $50-76$. https://doi.org/10.20961/jiep.v15i1.9894 
JPPM (Jurnal Pendidikan dan Pemberdayaan Masyarakat), 5 (2), 2018 - 166 Isti Larasati Widiastuty

Mankiw, N. G. (2003). Teori makro ekonomi (Terjemahan). Jakarta: Erlangga.

Momsen, J. H. (2013). Gender and development. Routledge.

Muhdar, H. (2015). Potret ketenagakerjaan, pengangguran, dan kemiskinan di Indonesia: Masalah dan solusi. AlBuhuts, 11(1), 42-66.

Okun, A. M., Fellner, W., \& Greenspan, A. (1973). Upward mobility in a highpressure economy. Brookings Papers on Economic Activity, 1973(1), 207-261.

Sekretariat Kabinet Republik Indonesia. (2018). Realisasi alokasi dana desa. Retrieved from https://setkab.go.id/?s=dana+desa\&lan $\mathrm{g}=\mathrm{id}$
Sulistyono, S., \& Sulistiyowati, W. (2017). Peramalan produksi dengan metode regresi linier berganda. PROZIMA (Productivity, Optimization and Manufacturing System Engineering), 1(2), 82. https://doi.org/10.21070/prozima.vii2.13 50

Tjiptoherijanto, P. (1999). Urbanisasi dan pengembangan kota di Indonesia. Populasi, 10(2), 57-72. https://doi.org/10.22146/jp.12484

Widodo, W. (2006). Analisis situasi pendidikan berwawasan gender di Propinsi Jawa Timur. Jurnal Humanity, 1(2), 122-128. Retrieved from http://ejournal.umm.ac.id/index.php/h umanity/article/view/108 